\title{
Transfer of Antibiotic Resistance Plasmid RP1 into Pseudomonas glycinea and Pseudomonas phaseolicola in vitro and in planta
}

\author{
By G. H. LACY AND J. V. LEARY \\ Department of Plant Pathology, University of California, Riverside, \\ California 92502, U.S.A.
}

(Received 28 August 1974; revised 20 December 1974)

\begin{abstract}
SUMMARY
The wide host-range antibiotic resistance plasmid RPI was transferred from Pseudomonas aeruginosa via Escherichia coli into Pseudomonas glycinea. The plasmid was then acquired by Pseudomonas phaseolicola both in vitro and in planta in Phaseolus limensis leaves and pods. This was the first step in the design of a model system to determine the possible epidemiological significance of antibiotic resistance plasmids in the control of plant disease.
\end{abstract}

\section{INTRODUCTION}

The possibility of $\mathrm{R}$ factor transfer among bacteria causing plant diseases which are routinely controlled by antibiotic therapy could have great epidemiological and economic implications. Recently, several studies have reported that phytopathogenic or phytosymbiotic species of bacteria were able to acquire plasmids in vitro. Chatterjee \& Starr $(\mathrm{I} 972 a, b)$ have transferred the fertility plasmid $\mathrm{F}^{\prime} l a c^{+}$and the resistance plasmid R Ioodrd into Erwinia spp. The same workers have achieved chromosomal transfer (Chatterjee \& Starr, I973). Various workers have transferred group P plasmids (Holloway \& Richmond, 1973) from Pseudomonas aeruginosa into Rhizobium spp. (Mattes et al. I973; Dunican \& Tierney, I973; O'Gara \& Dunican, 1973; Datta et al. I97I; Datta \& Hedges, I972). Datta \& Hedges (1972) also transferred $\mathrm{F}^{\prime} \mathrm{lac}^{+}$into Rhizobium lupini. Group P plasmids have been transferred to the phytopathogenic pseudomonads $P$. glycinea, $P$. lachrymans, $P$. phaseolicola and $P$. syringae (Panopoulos, Guimaraes \& Schroth, I973; Guimaraes, Panopoulos $\&$ Schroth, I973, I974) as well as the causative agent of crown gall, Agrobacterium tumefaciens (Datta \& Hedges, 1972).

If plasmids have a role in the epidemiology of antibiotic resistance in plant disease, then they must be transmissible on or in plant tissue. No studies have been directed at this premise.

However, plasmids are transferable under natural or simulated natural conditions. In vivo transfer of plasmids has been reported in the intestinal tract of gnotobiotic or antibiotic treated mice, pigs and humans (Schneider, Formal \& Baron, I96I; Jones \& Curtis, 1969; Mitsuhashi, 1971). Weinberg \& Statzky (1972) have evidence for plasmid transfer in sterile soil. These studies suggest that plasmids may be capable of movement from bacterium to bacterium in diverse natural environments.

This study was undertaken to determine if conjugal transfer of resistance plasmids was possible among species of phytopathogenic pseudomonads in planta as well as in vitro. This report forms the basis for a model upon which the epidemiological significance of in planta plasmid transfer in diseased plants may be tested. 
Table I. Origins of bacterial isolates

\begin{tabular}{|c|c|c|c|}
\hline Bacterium & Isolate & Genotype & Origin \\
\hline $\begin{array}{l}\text { Escherichia coli } \\
\text { Pseudomonas } \text { spp. }\end{array}$ & $\times 705$ & arg leu $\mathrm{Sm}^{\mathrm{r}} \mathrm{Cb}^{\natural} l a c^{+} \mathrm{F}^{-}$ & a \\
\hline$P$. aeruginosa & PAT9O4 ReV I & Prototroph* $\mathrm{Cm}^{\circledR} \mathrm{Sm}^{\mathrm{r}} \mathrm{RPI}^{+}$ & b \\
\hline P. fluorescens & PFOI 5.4 & met $\mathrm{Cm}^{s} \mathrm{Sm}^{\mathrm{r}} \mathrm{RPI}^{+}$ & b \\
\hline P. glycinea $\mathrm{R}-\mathrm{I}$ & LII3t & Prototroph $S m^{8} C b^{8}$ & c \\
\hline P. glycinea $\mathrm{R}-2$ & LI I 4 & cys thr $\mathrm{Sm}^{\mathrm{s}} \mathrm{Cb} b^{\mathrm{s}}$ & c \\
\hline P. glycinea $\mathrm{R}-5$ & LI I 5 & Prototroph $S m^{8} C b^{8}$ & c \\
\hline P. glycinea R-6 & PG9 & met $S m^{\mathrm{r}} C b^{\mathrm{s}}$ & d \\
\hline P. phaseolicola & HB36 & Prototroph $\mathrm{Sm}^{8} \mathrm{Cm}^{8} \mathrm{Cb}^{8}$ & d \\
\hline P. phaseolicola & HBIOY & Prototroph $\mathrm{Sm}^{\sharp} \mathrm{Cb}^{\mathrm{s}}$ & e \\
\hline P. phaseolicola & LI 24 & thi $S m^{\mathrm{r}} C b^{\mathrm{g}}$ & f \\
\hline
\end{tabular}

* The criterion for prototrophy was growth on Davis' MA or MB.

$\dagger$ The L-designations refer to the author's strain code.

¥ (a) Roy Curtiss III, University of Alabama, Birmingham, U.S.A.; (b) R. H. Olsen, University of Michigan Medical School, Ann Arbor, U.S.A.; (c) B. W. Kennedy, University of Minnesota, St Paul, U.S.A.; (d) M. N. Schroth, University of California, Berkeley, U.S.A.; (e) A. K. Vidaver, University of Nebraska, Lincoln, U.S.A.; (f) u.v. mutant of HBIOY.

\section{METHODS}

Origin of RPI. The wide host-range group $\mathrm{P}$ plasmid RPI, which confers resistance to carbenicillin $(\mathrm{Cb})$, tetracycline $(\mathrm{Tc})$, and kanamycin $(\mathrm{Km}) /$ neomycin $(\mathrm{Nm})$ (Lowbury et al. I969; Olsen \& Shipley, I973), was received in $P$. aeruginosa PAT904 Rev I from R. H. Olsen of the University of Michigan Medical School, Ann Arbor, U.S.A.

Origins of bacterial strains. These are given in Table I.

Inoculum preparation. Cells were cultured in Davis' minimal broth medium (MB) or complete broth without glucose (CB) for Escherichia coli (Lederberg, 1950) at $25^{\circ} \mathrm{C}$ and I $40 \mathrm{rev} . / \mathrm{min}$ on a shaker with a $2.5 \mathrm{~cm}$ rotational diameter for $\mathrm{I} 8$ to $22 \mathrm{~h}$.

In vitro RPI transfer. RPI was transferred in $\mathrm{CB}$ with the final suspensions of donor and recipient cells each adjusted to $10^{6}$ to $10^{7}$ colony forming units (c.f.u.) $/ \mathrm{ml}$ on the basis of $E_{600}$. The broth cultures were incubated under static conditions at $25^{\circ} \mathrm{C}$. Dilutions were streaked or spread on to the appropriate selective media to detect $\mathrm{RPI}^{+}$recipients.

In planta RPI transfer. Immature Phaseolus limensis (Fordhook 242 lima beans from W. Atlee Burpee Co., Ames, Iowa, U.S.A.) bean pods were inoculated by injection of $0.1 \mathrm{ml}$ distilled-water suspensions of washed recipient and donor cells adjusted to $10^{6}$ to $10^{7}$ c.f.u./ $\mathrm{ml}$. Leaflets of trifoliate leaves were inoculated by water congestion of the abaxial surface with a hand sprayer. Recipient and donor cells were applied consecutively. Leaflets were also lightly misted with bacterial suspensions to determine if transfer could take place on the leaf surfaces. The detached pods and leaflets were incubated at $25{ }^{\circ} \mathrm{C}$ under humid conditions (I00\% relative humidity) until assayed.

Extraction of bacterial cells from plant material. A minimum of ten bean leaflets and five bean pods were surface-disinfected in $\mathrm{I} \cdot 0$ to $\mathrm{I} \cdot 2 \%(\mathrm{~W} / \mathrm{v})$ aqueous sodium hypochlorite for $\mathrm{I}$ and $5 \mathrm{~min}$, respectively. The plant material was minced and blended to a paste. The paste was filtered through four layers of cheesecloth and rinsed with sterile water to a final volume of $100 \mathrm{ml}$. The filtrate was centrifuged, and the pellet washed twice by centrifugation at approximately $380 \mathrm{~g}$ for $\mathrm{I} 0 \mathrm{~min}$ and resuspended in $100 \mathrm{ml}$ of water. Ten misted leaves were produced as described in the previous paragraph and rinsed with sterile water to a final volume of $100 \mathrm{ml}$. Appropriate dilutions were plated on to selective media.

Selective media. Davis' minimal agar medium (Lederberg, 1950) was used unsupplemented 
as minimal agar (MA), supplemented with $500 \mu \mathrm{g} \mathrm{Cb} / \mathrm{ml}$ (Geopen provided by R. G. Meny and G. H. Stanley of Pfizer Inc., New York, U.S.A.) as MA $+\mathrm{Cb}$, supplemented with $20 \mu \mathrm{g}$ methionine (met) plus $25 \mu \mathrm{g}$ streptomycin $(\mathrm{Sm}) / \mathrm{ml}$ as $\mathrm{MA}+$ met $+\mathrm{Sm}$, or supplemented with $20 \mu \mathrm{g}$ Tc or $\mathrm{Nm} / \mathrm{ml}$ as $\mathrm{MA}+\mathrm{Tc}$ or $\mathrm{MA}+\mathrm{Nm}$. Eosin-methylene blue agar was fortified with $500 \mu \mathrm{g} \mathrm{Cb} / \mathrm{ml}$ and used as $\mathrm{EMB}+\mathrm{Cb}$. After inoculation all selective media plates were incubated at 25 or $37^{\circ} \mathrm{C}$ for 48 to $72 \mathrm{~h}$.

Confirmation of RPI transfer. Presumptive $\mathrm{RPI}^{+}$recipients were screened for appearance of multiple antibiotic resistance by replica-plating (Lederberg \& Lederberg, I952) on MA plus the appropriate antibiotic(s) or by plating on Davis' complete agar medium (CA), (Lederberg, 1950) and examining the zones of inhibition (z.o.i.) around antibiotic-sensitivity discs.

Phage PRRI specificity for plasmid-transformed cells. The male-specific phage PRRI (Olsen \& Shipley, I973; Olsen \& Thomas, 1974), specific for cells containing group P plasmids, was also supplied by R. H. Olsen. The phage was diluted in CB and allowed to adsorb to P. glycinea PG9 and PG9 RPI + for 5 to Io min. Dilutions were mixed with molten overlay agar (CB with $0.7 \%$ agar) at $45{ }^{\circ} \mathrm{C}$ and poured on CA plates. Incubation was at $25^{\circ} \mathrm{C}$ and any plaques were counted at $\mathrm{I} 8$ to $24 \mathrm{~h}$ after inoculation.

Host range determination. The host range of $P$. glycinea PG9 was compared with its plasmid-containing progeny to determine if any change had occurred due to the presence of RPI. The Glycine max (soybean) cultivars, Acme, Flambeau, Harosoy and Kanrich, the lima bean cultivar Fordhook 242, and the Phaseolus vulgaris (field beans) cultivar Romano pole beans, were included in the comparison.

Young primary leaves or nearly expanded trifoliate leaflets were inoculated by water congestion with bacteria washed twice by centrifugation and diluted to $10^{7}$ to $10^{8} \mathrm{c.f} . \mathrm{u} . / \mathrm{ml}$ in sterile, distilled water. The plants were observed periodically for 7 to 10 days in the greenhouse for the development of symptoms.

Stability of the plasmid in the recipient host cells. The stability of the plasmid host cell complex was compared in $P$. phaseolicola strains HI3IOY and HB36 and P. glycinea strain PG9. Cells were cultured in MB with antibiotics so that only resistant cells could develop. When the cell concentration reached $10^{7}$ c.f.u. $/ \mathrm{ml}$ the cells were transferred to $\mathrm{CB}$ and diluted to $10^{5}$ c.f.u./ml. Overnight cultures were washed by centrifugation, diluted, and spread on MA mixed with required nutrients. When colonies appeared, they were replicated on to $\mathrm{MA}+\mathrm{Tc}+\mathrm{Nm}$. Colonies were scored for growth on $\mathrm{MA}$ and on $\mathrm{MA}+\mathrm{Tc}+\mathrm{Nm}$. Any colonies not developing on the antibiotic-fortified agar were considered to have lost the plasmid spontaneously.

Curing of plasmids. The concentration of acridine orange (AO) causing inhibition of growth of PG9 $\mathrm{RPI}^{+}$cells in an overnight shake culture of $\mathrm{MB}+$ met was measured by $E_{600}$. Colonies which developed on $\mathrm{MA}+$ met, from cells exposed to $\mathrm{AO}$, were replicated to $\mathrm{MA}+$ met $+\mathrm{Cb}$ and scored for growth. Colonies which failed to replicate on the b-fortified medium were considered to have been cured of the plasmid.

Transfer frequency. The proportion of recipient cells acquiring the resistance plasmid was determined by the formula:

$$
\text { Transfer frequency }=\frac{\mathrm{RPI}^{+} \text {recipient colonies on } \mathrm{MA}+\mathrm{Cb}}{\text { recipient colonies on } \mathrm{MA}} .
$$


Table 2. In vitro and in planta transfer of $R P \mathrm{I}$ from $P$. glycinea $\mathrm{PG} 9$ met $S m^{\mathrm{r}} R P_{\mathrm{I}^{+}}$ to $P$. phaseolicola $\mathrm{HB} 36 \mathrm{Sm}$

\begin{tabular}{|c|c|c|c|c|c|}
\hline \multirow[b]{2}{*}{ Experiment } & \multirow{2}{*}{$\begin{array}{l}\text { Mating } \\
\text { period } \\
\text { (h) }\end{array}$} & \multicolumn{3}{|c|}{ Colony forming units $/ \mathrm{ml}$ mating suspension on: } & \multirow[b]{2}{*}{$\begin{array}{l}\text { Transfer } \\
\text { frequency } \dagger\end{array}$} \\
\hline & & $\begin{array}{c}\text { MA } \\
\text { (recipients) }\end{array}$ & $\begin{array}{c}\mathrm{MA}+\text { met }+\mathrm{Sm} \\
\text { (donors) }\end{array}$ & $\begin{array}{c}\mathrm{MA}+\mathrm{Cb} \\
\left(\mathrm{RPI}^{+} \text {recipients }\right)\end{array}$ & \\
\hline \multicolumn{6}{|l|}{ In vitro } \\
\hline I & $2 \cdot 0$ & $9.0 \times 10^{6}$ & $8.0 \times 10^{6}$ & $5.2 \times 10^{5}$ & $5.8 \times 10^{-2}$ \\
\hline 2 & $2 \cdot 0$ & $7.5 \times 10^{6}$ & ND & $8.0 \times 10^{4}$ & $\mathrm{I} \cdot \mathrm{I} \times 10^{-2}$ \\
\hline 3 & $2 \cdot 0$ & $7.5 \times 10^{6}$ & ND & $7.0 \times 10^{5}$ & $2.7 \times 10^{-2}$ \\
\hline $4^{*}$ & $2 \cdot 5$ & $1.0 \times 10^{7}$ & ND & $4.9 \times 10^{4}$ & $4.9 \times 10^{-3}$ \\
\hline 5 & $2 \cdot 0$ & $6.0 \times 10^{4}$ & $4.3 \times 10^{6}$ & $1 \cdot 3 \times 10^{3}$ & $2 \cdot 2 \times 10^{-2}$ \\
\hline \multicolumn{6}{|c|}{$\begin{array}{l}\text { In planta (Phaseolus lunatus - } \\
\text { Fordhook } 242 \text { lima beans) }\end{array}$} \\
\hline Pods & 6.5 & $I \cdot 2 \times 10^{6}$ & ND & $6.6 \times 10^{5}$ & $5.5 \times 10^{-1}$ \\
\hline Pods* & $2 \cdot 5$ & $5.0 \times 10^{6}$ & $3.8 \times 10^{6}$ & $2 \cdot 1 \times 10^{4}$ & $4.2 \times 10^{-3}$ \\
\hline \multicolumn{6}{|l|}{ Leaves } \\
\hline (congested) & 3.5 & $3.4 \times 10^{4}$ & $3.7 \times 10^{6}$ & $2.8 \times 10^{3}$ & $8.2 \times 10^{-2}$ \\
\hline \multirow{3}{*}{$\begin{array}{l}\text { Leaves } \\
\quad \text { (misted) }\end{array}$} & & & & & \\
\hline & $3 \cdot 5$ & $2.4 \times 10^{5}$ & $1 \cdot 2 \times 10^{7}$ & $7.5 \times 10^{4}$ & $3 \cdot \mathrm{I} \times 1 \mathrm{IO}^{-1}$ \\
\hline & culum & $\begin{array}{l}\text { red in MB } \\
\text { ee Methods }\end{array}$ & $\mathbf{M B}+\mathrm{met}+\mathrm{Sm}$ & rather than $\mathrm{CB}$. & \\
\hline
\end{tabular}

\section{RESULTS}

Direct transfer of RPI from $P$. aeruginosa PAT904 or P. fluorescens PFoI5.4 to phytopathogenic pseudomonads could not be accomplished. In the first series of transfer experiments, the phytopathogenicity of $P$. phaseolicola was used as the criterion for selection of $\mathrm{RPI}^{+}$recipients. Cultures were mixed in $\mathrm{CB}$ and enriched for $\mathrm{Cb}$ overnight in $\mathrm{CB}+\mathrm{Cb}$. No discrete lesions developed when the mixture of donor and recipients was inoculated on to Fordhook lima beans, although both PAT904 and PFOr 5.4 were re-isolated in nearly pure cultures. Selections of $\mathrm{RPI}^{+}$recipients were also attempted on the basis of auxotrophy versus prototrophy and of antibiotic resistance versus susceptibility. Similarly, no RPI+ recipients were isolated when the donors PAT90 $\mathrm{Cm}^{8} \mathrm{RPI}^{+}$and PFO $5.4 \mathrm{met}^{\mathrm{Cm}} \mathrm{RPI}^{+}$were mated with $P$. phaseolicola $\mathrm{LI} 24$ thi $\mathrm{Cm}^{\mathrm{r}} \mathrm{Cb}^{8}$ in $\mathrm{CB}$ and selection made in $\mathrm{MB}+\mathrm{Cb}$ plus $200 \mu \mathrm{g} \mathrm{Cm}$ and $20 \mu \mathrm{g}$ thiamine $/ \mathrm{ml}$.

Since direct transfer of RPI from PAT904 and PFOI5.4 was not detected, the plasmid was transferred into $E$. coli. This new host was used in subsequent experiments as a plasmid donor to phytopathogenic pseudomonads. Strain PAT904 was crossed with E. coli $\times 705$ in $\mathrm{CB}$, and selection was made by streaking or spreading the mating suspensions on $\mathrm{EMB}+\mathrm{Cb}$. The distinct morphology of $E$. coli lactose-fermenting $\left(\mathrm{Lac}^{+}\right)$colonies on EMB allowed differentiation from the light coloured Pseudomonas colonies. The phenotype, $\mathrm{x} 705 \mathrm{RPI}^{+}$, was recovered from $5^{\circ} 6 \times 10^{-3}$ of the recipient cells. The $E$. coli $l a c^{+} C^{\mathrm{r}}$ colonies were found to have acquired resistance to $\mathrm{Tc}, \mathrm{Nm}$ and $\mathrm{Km}$ when subcultured.

$\mathrm{RPI}$ was readily transferred from $E$. coli $\mathrm{X} 705 \mathrm{RPI}^{+}$in vitro and in planta (in pods) to $P$. glycinea PG9 and $P$. phaseolicola HBIOY. Selection for clones of the RPI ${ }^{+}$phytopathogens was also made by streaking or spreading suspensions of mating cells on EMB $+\mathrm{Cb}$. In this case the $\mathrm{lac}^{+} \mathrm{Cb}^{\mathrm{r}}$ Pseudomonas colonies were isolated from the streak plate. In vitro and in planta (in congested leaves) transfer frequencies of RPI from X705 to PG9 were $2 \cdot 8 \times 10^{-3}$ and 


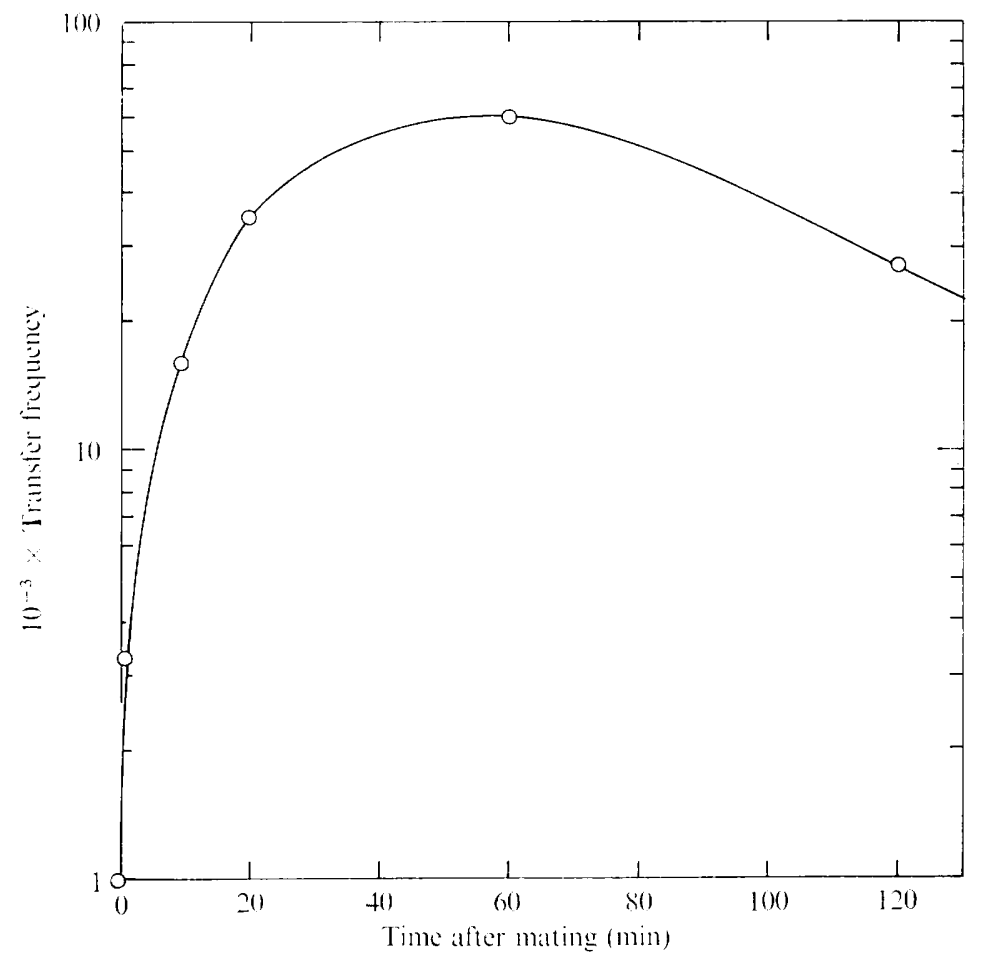

Fig. I. Representative data for the acquisition of RPI during in vitro mating of $P$. glycinea PG9 met $\mathrm{Sm}^{\mathrm{r}} \mathrm{RPI}^{+}$(donor) with $P$. phaseolicola $\mathrm{HB} 36 \mathrm{Sm}^{\mathrm{s}}$ (recipient). The cells were plated on $\mathrm{MA}+\mathrm{Cb}$ after agitation and dilution of the mating suspensions.

Table 3. Confirmation of RPI transfer from P. glycinea $\mathrm{PG} 9$ met $S m^{\mathrm{r}} R P \mathrm{I}^{+}$to $P$. phaseolicola HB36 $S^{8}$ by demonstration of multiple antibiotic resistance in colonies replicated from $M A+C b$

\begin{tabular}{|c|c|c|c|c|}
\hline \multirow[b]{3}{*}{ Experiment } & \multicolumn{3}{|c|}{ Number of colonies } & \\
\hline & \multirow{2}{*}{$\begin{array}{c}\text { Replicated from } \\
\mathrm{MA}+\mathrm{Cb}\end{array}$} & \multicolumn{3}{|c|}{ Growing on } \\
\hline & & $\mathrm{MA}+\mathrm{Tc}$ & $\mathrm{MA}+\mathrm{Nm}$ & $\mathrm{MA}+\mathrm{Sm}$ \\
\hline \multicolumn{5}{|c|}{ In vitro mating } \\
\hline $\mathbf{I}$ & IO2 & 9I & $9 I$ & 0 \\
\hline 2 & 399 & 399 & 0 & 0 \\
\hline \multicolumn{5}{|c|}{$\begin{array}{l}\text { In planta mating } \\
\text { (pods) }\end{array}$} \\
\hline 3 & 355 & 353 & 354 & 0 \\
\hline 4 & 205 & 199 & 203 & I \\
\hline
\end{tabular}

$\mathrm{I} \cdot 6 \times \mathrm{IO}^{-2}$ respectively. Plasmid transfer was confirmed by determining the recipient nutritional pattern and the plasmid antibiotic resistance markers in the same clone.

Further evidence for plasmid transfer to $P$. glycinea PG9 was derived from experiments with the P-specific phage PRRI. Numerous plaques were detected on lawns of $\mathrm{PG}_{\mathrm{P}} \mathrm{RPI}^{+}$but none on PG9.

RPI was successfully transferred from PG9 $\mathrm{RPI}^{+}$to $\mathrm{HB}_{3} 6$ in vitro and in planta (Table 2). In vitro acquisition of the plasmid by HB36 had reached a steady state in about 50 min (Fig. I). In $2 \mathrm{~h}$, an average of $3.0 \times 10^{-2}$ recipient $\mathrm{HB} 36$ cells acquired carbenicillin resistance. 
Table 4. Host reaction comparison of P. glycinea $\mathrm{PG} 9$ (R-6) and P. glycinea PG9 $\mathrm{RPI}^{+}$on soybeans, lima beans and pole beans

\begin{tabular}{|c|c|c|c|c|}
\hline & & Ho & & \\
\hline & Previc & ported & & tal \\
\hline & Reaction & Reference $\ddagger$ & PG9 & PG9 $\mathrm{RPI}^{+}$ \\
\hline Glycine $\max$ & & & & \\
\hline Acme* & $\mathrm{R}$ & a & $\mathrm{I}$ & I \\
\hline Flambeau* & $\mathrm{S}$ & a & $\mathbf{S}$ & $\mathbf{S}$ \\
\hline Harosoy* & $\mathbf{R}$ & a & $\mathbf{R}$ & $\mathbf{R}$ \\
\hline Kanrich $\dagger$ & - & 一 & $\mathbf{S}$ & $\mathbf{S}$ \\
\hline Phaseolus lunatus & & & & \\
\hline Fordhook $242 \uparrow$ & $\mathbf{S}$ & b & $\mathbf{S}$ & $\mathbf{S}$ \\
\hline P. vulgaris & & & & \\
\hline Romano† & 一 & - & $\mathbf{S}$ & $\mathbf{S}$ \\
\hline
\end{tabular}

Table 5. AO curing of RPI from P. glycinea PG9 recipients

\begin{tabular}{|c|c|c|c|}
\hline \multirow{2}{*}{$\underset{(\mu \mathrm{g} / \mathrm{ml})}{\mathrm{AO}}$} & \multicolumn{2}{|c|}{ Colonies developing on } & \multirow{2}{*}{$\begin{array}{l}\text { Percentage of } \\
\text { colonies failing } \\
\text { to develop on } \\
\mathrm{MA}+\text { met }+\mathrm{Cb}\end{array}$} \\
\hline & $\mathrm{MA}+$ met & $\mathrm{MA}+$ met $+\mathrm{Cb}$ & \\
\hline \multicolumn{4}{|c|}{ Expt 1} \\
\hline None & I 3 I & 130 & $0 \cdot 76$ \\
\hline I 5 & 67 & 63 & $5 \cdot 97$ \\
\hline None & 586 & 583 & 0.51 \\
\hline 15 & 525 & 519 & $I \cdot 14$ \\
\hline 20 & 662 & $65 I$ & $1 \cdot 66$ \\
\hline 30 & 303 & 280 & $7 \cdot 59$ \\
\hline
\end{tabular}

RPI transfer from PG9 RPI ${ }^{+}$to $\mathrm{HB}_{3} 6$ was confirmed by demonstrating multiple antibiotic resistance in the recipients by growth of colonies replicated from $\mathrm{MA}+\mathrm{Cb}$ on to $\mathrm{MA}$ containing Tc and $\mathrm{Nm}$. The chromosomal marker, $\mathrm{Sm}^{\mathrm{s}}$, in HB36 remained stable when tested by replicating colonies on to $\mathrm{MA}+\mathrm{Sm}$ (Table 3). Clones of the $\mathrm{RPI}^{+}$recipients were compared with parental strains for changes in their antibiotic sensitivity spectra consistent with acquisition of RPI. In all cases resistance to antibiotic discs containing $\mathrm{Tc}, \mathrm{Nm}$ and $\mathrm{Km}$ was observed.

RPI was transferred from PG9 RPI ${ }^{+}$to HBIOY and HB36 and could be transferred back to PG9. However, when PG9 pathogenic race 6 (Cross et al. 1966) was mated with $P$. glycinea race $\mathrm{I}$ or race 5 , transfer of the plasmid was not detected among approximately $10^{8} \mathrm{c.f} . \mathrm{u} . / \mathrm{ml}$. This was unexpected, since the organisms are very closely related.

No host range or pathogenicity changes caused by alterations of the cell anatomy or physiology due to the presence of the plasmid were detected. Strains PG9 and PG9 RPI ${ }^{+}$(compared on four cultivars of soybean, and one each of lima bean and pole bean) gave identical responses (Table 4) which were in general agreement with the published reactions (Cross et al. I966; Schroth, Vitanza \& Hildebrand, I97I). Flambeau and Harosy soybeans gave the expected susceptible and resistant reactions, Fordhook 242 lima beans were susceptible as 
described, but Acme soybeans gave an intermediate rather than resistant reaction with both PG9 and PG9 RPI ${ }^{+}$. Even though this reaction differed from the expected one, it was consistent for both PG9 and PG9 RPI ${ }^{+}$.

The stability of the plasmid-host cell complexes formed with the phytopathogenic pseudomonads was found to vary greatly. Strain PG9 formed a very stable complex with less than $\mathrm{I} \cdot 0 \%$ natural curing (Table 5), whereas HBIOY formed an unstable complex and it often showed 'double' z.o.i. around antibiotic discs. There was a marked decrease in the turbidity of the bacterial lawn coincident with the z.o.i of HBIOY recipient cells without the plasmid. However, growth did occur in the z.o.i., which indicated some resistance to all the plasmid antibiotic markers. Strain HB36 consistently lost the plasmid upon subculture if selection by multiple antibiotics was not maintained.

$\mathrm{AO}$ at 25 to $30 \mu \mathrm{g} / \mathrm{ml}$ was found to inhibit the growth of $\mathrm{I} 8$ to $25 \mathrm{~h}$ cultures of PG9 RPI ${ }^{+}$ cells. Two experiments showed that only $0.5 \mathrm{I}$ to $0.76 \%$ of the colonies replicated from $\mathrm{MA}+$ met to $\mathrm{MA}+$ met $+\mathrm{Cb}$ failed to develop when no AO was incorporated in the medium. However, as the concentration of AO increased, more colonies failed to replicate on the Cb-fortified medium (Table 5), indicating plasmid-curing.

\section{DISCUSSION}

Conjugal transfer of resistance plasmids was accomplished in vitro and in planta among the species of phytopathogenic pseudomonads investigated. The in planta transfer frequencies compared favourably with the in vitro ones. This, together with the ability of $E$. coli to transfer the plasmid into Pseudomonas spp. in bean pods, suggests that plasmid transfer between physiologically capable cells in planta is not limited by the host nor does it require a phytopathogen to phytopathogen relationship. Indeed, transfer appears to be independent of the host. The rapidity of the formation of mating pairs (see Fig. I) and the mating of bacteria in water suspensions in bean pods and leaves, suggests that exogeneous energy sources are unnecessary for the mating process. More important to the epidemiology of antibiotic resistance plasmids among phytopathogens is the rapidity of the exchange which occurs before the host plant's hypersensitive reaction could affect the physiology of recipient or donor cells. Bacterial populations do not decrease rapidly in many hypersensitive reactions (Allington \& Chamberlain, I949; Leben, Daft \& Schmitthenner, I968; Goodman, 1972; Keen \& Kennedy, 1974). Therefore, the transfer of antibiotic resistance plasmids from pathogenic races of bacteria incompatible with the resistant host could also be completed.

The failure of $P$. aeruginosa and $P$. fuorescens to transfer RPI to $P$. phaseolicola and $P$. glycinea PG9 directly, and the observation that $P$. glycinea PG9 could not transmit RPI to $P$. glycinea races I and 5, may suggest interference of bacteriocins rather than exclusion by an incompatible host. Indeed, bacteriocins have been found among isolates of $P$. phaseolicola $(8 \%)$ and $P$. glycinea (55\%) and other phytopathogens (Vidaver et al. 1972). Another possible explanation for failure of plasmid transfer may involve the presence of incompatible plasmids in the recipient (Datta \& Hedges, 197I; Willets, 1972).

The plant-pathological significance of the transfer of resistance plasmids in plants may be more than a simple model for the epidemiology of infectious resistance to antibiotic chemotherapy. It has been reported that RPI and several related plasmids have fertility functions (Stanisich \& Holloway, I971; Holloway \& Richmond, 1973). If these plasmids could mobilize and transfer chromosomes of phytopathogenic bacteria, insight could be gained into the nature of genes for 'pathogenicity' and 'virulence'. Genetic studies of pathogenicity in phytopathogenic pseudomonads may provide more profitable systems than 
those employing intestinal pathogens of man, because of the intimate host-parasite relationships in the former, including specific host reactions and the existence of physiological races of pathogens.

We thank the investigators who sent us bacterial strains and phage, and Professors W. L. Belser Jun., D. D. Focht, N. T. Keen and W. W. Thomson for their critical reviews of the manuscript. This work was submitted by G.H.L. in partial fulfillment of the requirements for a Ph.D. degree at the University of California.

\section{REFERENCES}

Allington, W. B. \& Chamberlain, D. W. (1949). Trends in the population of pathogenic bacteria within leaf tissues of susceptible and immune plant species. Phytopathology 39, 656-660.

Chatterjee, A. K. \& Starr, M. P. (1972a). Genetic transfer of episomic elements among Erwinia species and other enterobacteria: $\mathrm{F}^{\prime} l a c^{+}$. Journal of Bacteriology III, I69-176.

Chatterjee, A. K. \& Starr, M. P. (1972 b). Transfer among Erwina spp. and other enterobacteria of antibiotic resistance carried on R factors. Journal of Bacteriology 112, 576-584.

Chatterjee, A. K. \& Starr, M. P. (1973). Gene transmission among strains of Erwinia amylovora. Journal of Bacteriology I16, I 100-1 106.

Cross, J. E., Kennedy, B. W., Lambert, J. W. \& Cooper, R. L. (1966). Pathogenic races of the bacteria blight pathogen of soybeans, Pseudomonas glycinea. Plant Disease Reporter 50, 557-560.

DATTA, N. \& HEDGES, R. W. (I97I). Compatibility groups among $f$ R factors. Nature, London 234, 222-234.

DATTA, N. \& HeDGes, R. W. (1972). Host ranges of R factors. Journal of General Microbiology 70, 453-460.

Datta, N., Hedges, R. W., Shaw, E. J., Sykes, R. B. \& Richmond, M. H. (I97I). Properties of an R factor from Pseudomonas aeruginosa. Journal of Bacteriology 108, I244-1249.

DuniCAN, L. K. \& TIERNEY, A. B. (1973). Transformation of an R-factor from Pseudomonas aeruginosa into Rhizobium trifolii. Molecular and General Genetics 126, I87-190.

Goodman, R. N. (1972). Electrolyte leakage and membrane damage in relation to bacterial population, $\mathrm{pH}$ and ammonia production in tobacco leaf tissue inoculated with Pseudomonas pisi. Phytopathology 62, I327-r33I.

Guimaraes, W. V., Panopoulos, N. J. \& Schroth, M. N. (1973). R factor transfer from Pseudomonas aeruginosa to Pseudomonas syringae and to saprophytic pseudomonads. In 2nd International Congress of Plant Pathology, University of Minnesota, Sept. 5-12, I973, Abstracts of Papers.

Guimaraes, W. V., Panopoulos, N. J. \& Schroth, M. N. (1974). New R factors transferred to plant pathogenic pseudomonads. American Phytopathological Society, Proceedings of the Annual Meetings, p. 163 .

Holloway, B. W. \& Richmond, M. H. (1973). R-factors used for genetic studies in strains of Pseudomonas aeruginosa and their origin. Genetical Research 2r, 103-105.

JoNes, R. T. \& CURTISS, R., III. (I969). Genetic exchange between Escherichia coli KI2 strains in the intestinal tract of mice. Bacteriological Proceedings 66-67.

KeEN, N. T. \& KenNedY, B. W. (1974). Hydroxyphaseollin and related isoflavanoids in the hypersensitive resistant response of soybeans against Pseudomonas glycinea. Physiological Plant Pathology 4, 173-185.

LeBen, C., DAFT, S. C. \& SChMitThenNer, A. F. (1968). Bacterial blight of soybeans: population levels of Pseudomonas glycinea in relation to symptom development. Phytopathology 58, 1 I43-I I46.

LEDERBERG, J. (1950). Isolation and characterization of biochemical mutants of bacteria. Methods in Medical Research 3, 5-22.

LeDerberG, J. \& LeDerberg, E. M. (1952). Replica plating and indirect selection of bacterial mutants. Journal of Bacteriology 63, 399-406.

Lowbury, E. J. L., Kidson, A., Lilly, H. A., Ayliffe, G. A. J. \& Jones, R. J. (1969). Sensitivity of Pseudomonas aeruginosa to antibiotics: emergence of strains highly resistant to carbenicillin. Lancet ii, 448-452.

Mattes, R., Burkardt, H. J., Heumann, W. \& Phuler, A. (1973). R factors from Pseudomonas aeruginosa investigated in Rhizobium lupini and Escherichia coli. Genetics 74, SI75 (abstract).

Mitsuhashi, S. (1971). Epidemiology and genetics of R factors. Annals of the New York Academy of Science 182, I4I-I 52.

O'Gara, F. \& DunicaN, L. K. (1973). Transformation and physical properties of R-factor RP4 transferred from Escherichia coli to Rhizobium trifolii. Journal of Bacteriology II6, I I77-I I80. 
Olsen, R. H. \& Shipley, P. (1973). Host range and properties of the Pseudomonas aeruginosa R factor Ri822. Journal of Bacteriology I13, 772-780.

Olsen, R. H. \& Thomas, D. D. (1974). Characteristics and purification of PRRI, and RNA phage specific for the broad host range Pseudomonas R I 822 drug resistance plasmid. Journal of Virology I2, I 560-I 567.

Panopoulos, N. L., Guimaraes, W. V. \& Schroth, M. N. (1973). Transfer of R factor carrying carbenicillin resistance to plant pathogenic pseudomonads. Phytopathology 63, I 217 (abstract).

Schneider, H., Formal, S. B. \& Baron, L. S. (1961). Experimental genetic recombination in vivo between Escherichia coli and Salmonella typhimurium. Journal of Experimental Medicine 114, 141-I48.

Schroth, M. N., Vitanza, V. B. \& Hildebrand, D. C. (I97I). Pathogenic and nutritional variation in the halo blight group of flourescent pseudomonads of bean. Phytopathology 6r, 853-857.

Stanisich, V. A. \& Holloway, B. W. (I97I). Chromosome transfer in Pseudomonas aeruginosa mediated by R-factors. Genetics Research 17, I69-172.

Vidaver, A. K., Mathys, M. L., Thomas, M. E. \& Schuster, M. L. (1972). Bacteriocins of the phytopathogens Pseudomonas syringae, P. glycinea and P. phaseolicola. Canadian Journal of Microbiology 18 , 705-713.

Weinberg, S. R. \& Stotzky, G. (1972). Conjugation and genetic recombination of Escherichia coli in soil. Soil Biology Biochemistry 4, 17 I-180.

Willets, N. (1972). The genetics of transmissible plasmids. Annual Review of Genetics 5, 257-268. 